\title{
THE PRESENCE OF BARK IN Acacia mangium WOOD IMPROVES ITS ENERGETIC POTENTIAL
}

\author{
Brenda Rodrigues Souza ${ }^{1}$, Mariana Dianese Alves de Moraes ${ }^{1}$, Frederico Severino Braboza ${ }^{2}$, Ademilson \\ Coneglian ${ }^{2}$, Carlos Roberto Sette $\mathrm{Jr}^{1 *}$
}

\author{
${ }^{1}$ Universidade Federal de Goiás, Departamento de Engenharia Florestal, Goiânia. Goiás. Brasil - e-mail: brenda_florestal@ hotmail.com; \\ maridianese@gmail.com; crsettejr@hotmail.com \\ ${ }^{2}$ Universidade Estadual de Goiás, Departamento de Engenharia Florestal, Ipameri, Goiás, Brasil - e-mail: undefined sbfrederico@ gmail.com; \\ coneglian@ueg.br
}

Received for publication: 06/06/2019 - Accepted for publication: 11/12/2019

\begin{abstract}
Resumo
A presença da casca na madeira de Acácia mangium melhora o seu potencial energético. A utilização da casca associada com a madeira de espécies florestais, para a geração de energia, pode ser uma alternativa viável do ponto de vista técnico, ambiental e econômico. O trabalho teve como objetivo avaliar o efeito da adição da casca nas características da madeira e de briquetes de Acácia mangium e Eucalyptus urophylla x Eucalyptus grandis (urograndis). Árvores das duas espécies, com 7 anos de idade, foram cortadas de experimento de campo e obtidas amostras de madeira com e sem casca para a avaliação das características físico-energéticas da biomassa e briquetes. A presença da casca na madeira da A. mangium melhorou as suas características energéticas, sendo viável do ponto de vista técnico a sua utilização, em pequenas quantidades, em conjunto com a madeira para aplicações energéticas. A adição da casca em pequenas quantidades na madeira do Urograndis promoveu a redução das suas características energéticas. As características dos briquetes não foram influenciadas pela espécie e presença da casca.

Palavras-chave: Espécies florestais alternativas; bioenergia; briquetes; Eucalyptus
\end{abstract}

\begin{abstract}
The use of the wood associated with the bark of forest species for energy purposes can be a viable alternative from the technical, environmental and economic points of view. The objective of this study was to evaluate the effect of maintaining the bark on the energetic characteristics of Acacia mangium and Eucalyptus urophylla $\mathrm{x}$ Eucalyptus grandis (urograndis) wood and briquettes. Trees of both species of 7 years old were cut from field experiments and wood samples with and without bark were obtained to evaluate the physical and energetic characteristics of the biomass and briquettes. The presence of bark in A. mangium wood improved the energetic characteristics of the biomass, and its use in small quantities together with wood for energy applications is technically feasible. Maintaining the bark in small quantities in the Urograndis wood promoted a reduction in the energetic characteristics of the biomass. The characteristics of the briquettes were not influenced by the species or the presence of bark in the wood.

Keywords: Alternative forest species; bioenergy; briquetes; Eucalyptus.
\end{abstract}

\section{INTRODUCTION}

The wood from short-rotation forests plantation are relevant sources of biomass for energy purposes and the eucalyptus species are the most widely planted in Brazil. In order to diversify biomass sources, it is sought to establish commercial plantations using alternative forest species with good adaptation, which present rapid volumetric growth and wood quality for energy purposes.

The Acacia genus has been widely accepted for reforestation, with a gradual increase in the area planted in Brazil, totaling 162,000 ha in 2018 (INDUSTRIA BRASILEIRA DE ÁRVORES, 2019). Acacia species are important economically in various parts of the world, and some common uses include as a source of wood, feedstock to produce pulp and paper, tannin, and source of high quality biomass (AHMED et al., 2018).

Most of the wood used, such as wood-based panels, paper and cellulose and others depends on the removal of bark from logs during the industrialization process (LOPES et al., 2016). Therefore, bark is a significant residue and can be used to producing biofuel (REINA et al., 2016). However, the direct application of the bark as an energetic source presents disadvantages in relation to wood, mainly due to the high ash content and low heating value (SETTE Jr et al., 2018), and its use associated with wood can be an alternative, eliminating the process of its removal during wood processing, reducing solid residue generation and production costs.

In Brazil, the Acacia mangium Willd. is one of the most planted species of Acacia genus and the bark is used for tannin extraction. However, the biomass of this species, including bark, has been used for energy purposes in various regions of the world (POHLMANN et al., 2014; MARQUEZ-MONTESINO et al., 2015; CHARUSIRI et al., 2017). Thus, may be an alternative for forestry plantations for energy purposes, especially for it presents rusticity and adaptability to adverse soil and climate conditions, rapid growth and high biomass production (DUARTE et al., 2011).

FLORESTA, Curitiba, PR, v. 51, n. 1, p. 054-060, jan/mar 2021.

Souza, B. R. et.al.

ISSN eletrônico 1982-4688

DOI: $10.5380 /$ rf.v51 i1. 67299 
Likewise, the direct use of the biomass (bark, wood or wood + bark) in a natural form, for energy purpose, presents some unfavorable characteristics related to the high moisture content, low mass and energetic density. One of the possibilities for reducing or eliminating the main problems associated with the direct use of biomass is through compaction processes, such as pelletization and briquetting.

The aim of this study was to evaluate the characteristics of A. mangium and Eucalyptus urophylla $\mathrm{x}$ Eucalyptus grandis wood and wood + bark, targeting the generation of energy in natura and densified as briquettes.

\section{MATERIAL AND METHODS}

\section{Characterization of the experimental area}

The experiment was conducted at the experimental farm of the State University of Goiás, Ipameri Campus, Goiás, Brazil (Geographic coordinates; 17 43' 19" S latitude and 48 09' 35" W longitude, and altitude of $764 \mathrm{~m}$ ). The predominant climate of the region is defined as tropical humid, with a rainy season in the summer and dry in the winter, according to the Köppen classification. The soil is classified as dystrophic red latosol, presenting a clayey texture.

Eucalyptus urophylla S.T. Blake x Eucalyptus grandis W. Mill ex Maiden (Urograndis) and Acacia mangium (Acacia) seedlings were planted in $3 \times 2 \mathrm{~m}$ spacings. The area was prepared according to the conventional system with plowing and harrowing, and the $\mathrm{pH}$ of the soil was corrected by applying 2 tons of limestone, PRTN $92 \%$. At planting, $100 \mathrm{~g}$ of $05-25-15 \mathrm{NPK}+0.5 \%$ of $\mathrm{Zn}$ and $10 \mathrm{~g}$ per plant of boric acid was used. Cover fertilization was performed at the age of 6 months with $150 \mathrm{~g}$ NPK $05-25-15+0.5 \% \mathrm{Zn}$.

\section{Tree selection, cutting and sample preparation}

Ten trees of each species were randomly selected at 7 years old, totaling 20 trees sampled. The dendrometric data (DBH: diameter at breast height and total height) of the selected trees were determined.

The trees were cut and two wooden discs $(5 \mathrm{~cm}$ thick each) were removed in different longitudinal positions of the trunk (Base: $0 \%, \mathrm{DBH}, 25 \%, 50 \%, 75 \%$ and $100 \%$ of commercial height). One wooden disc had the bark removed and the other remained with the bark intact. Thus, two conditions were established: (i) wood with bark; and (ii) wood without bark. The percentage of bark was calculated by measuring the total wooden disc diameter and bark thickness.

The wooden disks with and without bark were segmented into wedges, two of which were used to determine the wood basic density (NBR 11941/2003), and the other two were transformed into sawdust using a Willey knife mill. The sawdust was grouped together to form a composite sample with the biomass of the different longitudinal trunk positions.

\section{Wood characterization}

In order to determine the wood characteristics by specie and conditions, a part of the composite wood with and without bark (with samples of all the longitudinal trunk positions) was submitted to a mechanical separation in an orbital shaker using intermittent sieves. The retained fraction in the 60 mesh sieve was used.

The procedure for the proximate analysis was based on ASTM E872-82 and ASTM D1102-84, determining the content of volatile materials, ash and fixed carbon. The high heating value (HHV) was determined by a calorimetric pump following the ASTM D5865-13 standard, and the wood energetic density was calculated by the product of the HHV and the wood basic density.

\section{Production and characterization of briquetes}

The wood milled with and without bark was dried at $105{ }^{\circ} \mathrm{C}\left( \pm 2{ }^{\circ} \mathrm{C}\right)$ until constant weight and the moisture content was adjusted to $12 \%$ using a water sprayer and precision scale, as proposed by Sette et al. (2018).

The wood compaction was performed using laboratory equipment with a temperature of $120 \pm 5{ }^{\circ} \mathrm{C}$, a pressure of $140 \mathrm{kgf} \mathrm{cm}^{-2}$, compaction time of 5 minutes and cooling of 10 minutes with forced ventilation. The compaction conditions of the wood were defined by preliminary tests of pressing time and cooling. For each briquette, $40 \mathrm{~g}$ of milled wood was used, to finally obtain a briquette of approximately $4 \mathrm{~cm}$ in length and $3 \mathrm{~cm}$ in diameter, producing 10 briquettes per condition (with and without bark) and specie (Urograndis and Acacia), totaling 40 briquettes.

The following parameters were determined:

(i) apparent density by the stereometric method using the volume and mass data of each briquette;

(ii) low heating value (LHV), using 12\% moisture content of briquettes (Sette Jr et al., 2018);

(iii) energetic density, calculated by the product of LHV and the apparent density; 
(iv) durability, determined by mass loss of the briquettes, as described by Liu et al. (2014), in which the briquettes were weighed to obtain the initial mass, submitted to the orbital sieve shaker for 10 minutes and then weighed to obtain the final mass;

(v) tensile strength by diametric compression, obtained in an EMIC - DL30000 universal testing machine, with a load cell of $500 \mathrm{kgf}$ at a constant speed of $0.3 \mathrm{~mm} \mathrm{~min}$. This test measures the simple tensile strength, based on the principle that a diametrically loaded cylinder receives tensile stresses in addition to those of compression; since the tensile strength of the briquettes is numerically much lower than that of compression, it ruptures by tensile.

(vi) volumetric expansion, calculated from the briquette volume increment at two different times: immediately and 72 hours after briquetting.

\section{Statistical analysis}

The experimental design was completely randomized. The effect of the species and condition (wood with and without bark) was evaluated. The mean values generated in both conditions (with bark and without bark) were considered for determining the effect of the species. Outliers, data distribution and variance heterogeneity were measured. The data were submitted to analysis of variance and the means were compared by the Student's t-test at $5 \%$ probability.

\section{RESULTS}

\section{Wood characteristics}

The dendrometric data are presented in Table 1, with significant effect of specie in the bark percentage.

Table 1. Dendrometric characteristics and bark percentage of the selected trees.

Tabela 1. Características dendrométricas e porcentagem de casca das árvores selecionadas.

\begin{tabular}{lcccc}
\hline Species & Parameters & DBH with bark $(\mathrm{cm})$ & Total height $(\mathrm{m})$ & Bark $(\%)$ \\
\hline Urograndis & Mean & 25.7 & 20.2 & 6.7 \\
& Maximum & 26.8 & 21.4 & 7.3 \\
& Minimum & 24.3 & 18.8 & 5.6 \\
& CV (\%) & 3.8 & 5.6 & 10.3 \\
& Standard deviation & 0.9 & 1.1 & 0.6 \\
\hline Acacia & Mean & 27.2 & 17.1 & $14.6^{*}$ \\
& Maximum & 29.5 & 19.0 & 17.5 \\
& Minimum & 25.2 & 15.8 & 11.7 \\
& CV (\%) & 6.6 & 8.8 & 15.8 \\
& Standard deviation & 1.8 & 1.5 & 2.3 \\
\hline
\end{tabular}

Legend: DBH: Diameter at breast height; CV: Coefficient of variation. Student's t-test: * p<0.05.

Significant effects of the species and of the conditions were observed for the proximate analysis and $\mathrm{HHV}$, as indicated in Table 2.

Table 2. Energy characteristics of biomass per specie and condition.

Tabela 2. Características energéticas da biomassa por espécie e condição.

\begin{tabular}{lccccc}
\hline Species & Condition & $\begin{array}{c}\text { Volatile } \\
(\%)\end{array}$ & $\begin{array}{c}\text { Ash } \\
(\%)\end{array}$ & $\begin{array}{c}\text { Fixed carbon } \\
(\%)\end{array}$ & $\begin{array}{c}\text { HHV } \\
\left(\mathrm{MJ} \mathrm{kg}^{-1}\right)\end{array}$ \\
\hline Urograndis & with bark & 86.09 & $0.48^{*}$ & 13.42 & 19.01 \\
& without bark & 85.49 & 0.34 & 14.16 & $19.32^{*}$ \\
\hline Mean & & 85.79 & 0.41 & 13.79 & 19.17 \\
\hline Acacia & with bark & 80.45 & $0.48^{*}$ & $19.06^{*}$ & $20.63^{*}$ \\
& without bark & $84.89 *$ & 0.41 & 14.70 & 19.58 \\
\hline Mean & & 82.67 & $0.44^{* *}$ & 16.88 & $20.10^{* *}$ \\
\hline
\end{tabular}

Legend: HHV: High heating value; Student's t-test: *condition; **species $\mathrm{p}<0.05$

No significant differences were observed for the wood basic density among the species and conditions. The maintaining of bark in the Acacia wood promoted an increase in energetic density (Table 3). 
Table 3. Physical-energetic characteristics of wood per specie and condition.

Tabela 3. Características físico-energéticas da madeira por espécie e condição.

\begin{tabular}{lccc}
\hline Species & Condition & $\begin{array}{c}\text { WBD } \\
\left(\mathrm{kg} \mathrm{m}^{-3}\right)\end{array}$ & $\begin{array}{c}\text { WED } \\
\left(\mathrm{MJ} \mathrm{m}^{-3}\right)\end{array}$ \\
\hline Urograndis & with bark & 430 & 8,174 \\
& without bark & 450 & 8,694 \\
\hline Mean & & 440 & 8,434 \\
\hline Acacia & with bark & 470 & $9,696^{*}$ \\
\hline Mean & without bark & 450 & 8,811 \\
\hline
\end{tabular}

Legend: WBD: Wood basic density; WED: Wood energetic density. Student's t-test: *condition; **species p<0.05

\section{Characteristics of briquettes}

The evaluation of the physical-mechanical and energetic characteristics of the briquettes indicated a significant effect of the species and the condition only to the useful heating value and the volumetric expansion (Table 4).

Table 4. Physical-mechanical and energetic characteristics of briquettes per specie and condition. Tabela 4. Características físico-mecânicas e energéticas dos briquetes por espécie e condição.

\begin{tabular}{|c|c|c|c|c|c|c|c|}
\hline Species & Condition & $\begin{array}{c}\mathrm{AD} \\
\left(\mathrm{kg} \mathrm{m}^{-3}\right)\end{array}$ & $\begin{array}{c}\mathrm{LHV} \\
\left(\mathrm{MJ} \mathrm{kg}^{-1}\right)\end{array}$ & $\begin{array}{c}\mathrm{ED} \\
\left(\mathrm{MJ} \mathrm{m}^{-3}\right)\end{array}$ & $\begin{array}{c}\text { EXP } \\
(\%)\end{array}$ & $\begin{array}{c}\text { DUR } \\
(\%)\end{array}$ & $\begin{array}{l}\text { TSDC } \\
(\mathrm{MPa})\end{array}$ \\
\hline \multirow[t]{2}{*}{ Urograndis } & with bark & 1,170 & 15.19 & 17,772 & $0.91 *$ & 99.66 & 4.79 \\
\hline & without bark & 1,170 & $15.40^{*}$ & 18,018 & 0.56 & 99.62 & 4.54 \\
\hline Mean & & 1,170 & 15.29 & 17,889 & 0.73 & 99.64 & 4.67 \\
\hline \multirow[t]{2}{*}{ Acacia } & with bark & 1,180 & $16.67 *$ & 19,670 & $3.00 *$ & 99.74 & 4.87 \\
\hline & without bark & 1,210 & 15.76 & 19,069 & 2.56 & 99.49 & 4.74 \\
\hline Mean & & 1,195 & $16.21 * *$ & $19,370 * *$ & $2.78 * *$ & 99.62 & 4.81 \\
\hline
\end{tabular}

Legend: AD: Apparent density; LCV: Low heating value; ED: Energetic density; EXP: Expansion; DUR: durability; TSDC: tensile strength by diametrical compression. Student's t-test: *condition; **species $\mathrm{p}<0.05$

\section{DISCUSSION}

The evaluation of the wood quality characteristics is essential, as it provides support to predict the energetic potential of species and biofuels, as well as their viability of use, thus enabling a comparison of fast growing forest species for energetic purposes.

The bark percentage on the trunk of Acacia trees was higher (14.6\% of trunk volume) than the Urograndis (6.7\% of trunk volume). Silva et al. (2018) obtained high bark contents in A. mangium planted in monoculture and indicate the hypothesis that when planted in denser spacing, the specie produces more bark as a response to stress by competition for nutrients, water and light.

Maintaining small amounts of bark in Acacia wood improved the wood energetic characteristics (Table 2). As improvements, we can mention the increase in $\mathrm{HHV}$ (19.58 to $20.63 \mathrm{MJ} \mathrm{kg}^{-1}$ ) and the fixed carbon content (14.7 to $19.1 \%$ ). This result may be related to the chemical composition of A. mangium bark, as demonstrated by Rosdiana et al. (2017) and Vega et al. (2019), with total extractives content in the order of 17-34\%, higher than the extractives content found in the wood of this same specie, between 4-6\% (BOONDAENG et al., 2015; VEGA et al., 2019). In its chemical composition, bark differs from wood by the presence of polyphenols and a higher percentage of extractives (ROSDIANA et al., 2017). The large amount of tannins and phenolic compounds (ZHANG et al., 2010), which are normally used by the industry, for example in the extraction of dyes for tissues may also contribute to improve the energetic characteristics.

The extractives contribute significantly to the increase of the fixed carbon content in the wood and bark: a linear and positive correlation is usually observed (ALONSO et al., 2017). In the same way, the fixed carbon content is directly related to the high heating value observed in several biomasses (MOYA and TENORIO, 2013); the increase of fixed carbon contents is associated with high HHV values. Thus, higher levels of extractives in Acacia bark may contribute to the increase of fixed carbon and HHV, as observed in this study (Table 2).

FLORESTA, Curitiba, PR, v. 51, n. 1, p. 054-060, jan/mar 2021.

Souza, B. R. et.al.

ISSN eletrônico 1982-4688

DOI: 10.5380/rf.v51 i1. 67299 
For future studies and a better understanding of the positive energetic effects of maintaining the bark in the wood for Acacia, it is recommended to carry out chemical analyzes with the determination of lignin, holocellulose and extractives contents.

Different from that observed for Acacia, maintaining the bark in small quantities in the Urograndis wood (6.7\% of trunk volume) promoted a reduction in the wood energetic characteristics, as also observed by Sette Jr $e t$ al. (2018) for the same hybrid and age. In general, the bark of forest species presents a large amount of minerals, reducing their energetic potential.

Despite the differences observed between the species for the ash content, the average values are within the range indicated for several forest species and within the minimum requirements levels for the commercialization of wood briquettes, as recommended by ENplus DIN EN ISO 17225-3. The ash content is a relevant parameter for designing a boiler and its cleaning; biomass combustion with high ash content will require a more regular and efficient removal process. The ash is abrasive and can cause corrosion of the metal elements in the burners in the long term (LIU et al., 2014).

No significant differences were observed for the wood basic density between species and conditions with and without bark. This result may be associated with similar growth conditions for the two species studied, with no difference between trunk diameters (DBH) and total height (Table 1). The growth rate in trunk diameter has a significant influence on wood characteristics, especially on the wood basic density, as indicated by Sette Jr et al. (2016).

Maintaining the bark in the wood provided an increase in energetic density for Acacia (Table 3) as a function of the increase in HHV also observed for this condition. The energetic density is proportional and influenced by the heating value and represents the amount of energy per volume of material; thus, the higher the energetic density, better the wood performance as fuel.

Removal of the bark from the logs during the industrialization process takes place in most of the wood applications, resulting in a large amount of this residue, and its incorporated use in wood biomass can constitute an interesting possibility from the point of view of energetic, as found in this study for Acacia.

The variables evaluated for the briquettes were not influenced by the specie and condition (with and without bark), except for low heating value (LHV) and volumetric expansion (Table 4). The homogeneity of the briquettes characteristics is related to the briquetting process conditions (pressure and temperature), which tend to influence the physico-mechanical properties of the densified materials in a more significant way (CARONE et al., 2011), making the average values homogeneous. The similar wood basic density between conditions and species (Table 3) also may be influencing the homogeneity of values.

The LHV was higher for the Acacia than the Urograndis briquettes and in wood with (Acacia) and without bark (Urograndis) as a function of the higher average values observed for the HHV of the biomass in these conditions, before the compactation, since the moisture content of the briquettes did not change.

A statistical difference was found for the briquette expansion. The briquettes with the bark presented higher values for the two studied species (Table 4). The expansion behavior of the briquettes differs according to the characteristics of the biomass used. Maintaining the bark considerably influenced its volumetric expansion, especially for Acacia. The main factor responsible for volumetric expansion of the briquettes is the chemical composition of the biomass such as holocellulose, lignin and extractives (Sette Jr et al., 2018). In this sense, the higher levels of extractives present in Acacia bark, as indicated in the literature, especially the hydrophilics, may be contributing to water absorption and consequently to the greater expansion of briquettes.

The densification of the biomass significantly increased the mass density by 2.5 times: from $440-460 \mathrm{~kg}$ $\mathrm{m}^{-3}$ in the wood to $1,170-1,195 \mathrm{~kg} \mathrm{~m}^{-3}$ in the briquettes. The increase after compaction, as expected, is a function of the pressure exerted on the biomass compaction, causing the final density of the briquette to be higher, and reflecting in an increase in energetic density.

\section{CONCLUSIONS}

- Maintaining the bark in the A. mangium wood improved the energetic characteristics and its use in small quantities together with wood for energetic applications is technically feasible.

- Maintaining the bark in the Eucalyptus urophylla x Eucalyptus grandis wood promoted a reduction in the energetic characteristics.

- The briquettes characteristics were not influenced by the species or maintaining the bark in the wood. 


\section{REFERENCES}

AHMED, A.; BAKAR, M.S.A.; AZAD, A.K.; SUKRI, R.S.; MAHLIA, T.M.I. Potential thermochemical conversion of bioenergy from Acacia species in Brunei Darussalam: A review. Renewable and Sustainable Energy Reviews, v.82, n.3, p. 3060-3076, 2018.

ALONSO, M. Z.; TRAN, K.; WANG, L.; SKREIBERG, Ø. A kinetic study on simultaneously boosting the mass and fixed-carbon yield of charcoal production via atmospheric carbonization. Energy Procedia, v. 120, p. 333340, 2017.

ASSOCIAÇÃO BRASILEIRA DE NORMAS TÉCNICAS. NBR 11941: Madeira - Determinação da densidade básica. Rio de Janeiro, 2003.

ASTM D1102-84. Standard Test Methods for Ash in Wood (2007) West Conshohocken, PA.

ASTM D5865-13. Standard Test Method for Gross Calorific Value of Coal and Coke (2013). West Conshohocken, PA.

ASTM E872-82. Standard Test Methods for Volatile Matter in the Analysis of Particulate Wood (2006). West Conshohocken, PA.

BOONDAENG A.; VAITHANOMSAT P.; APIWATANAPIWAT W.; TRAKUNJAE C.; KONGTUD W. Statistical approach for optimization of ethanol production from fast-growing trees: Acacia mangium and Acacia hybrid. BioResources, v. 10 n.2, p. 3154-3168, 2015.

CARONE, M. T.; PANTALEO, A.; PELLERANO, A. Influence of process parameters and biomass characteristics on the durability of pellets from the pruning residues of Olea europaea L. Biomass and Bioenergy, v. 35 p. 402 $-410,2011$.

CHARUSIRI, W.; NUMCHAROENPINIJ, N. Characterization of the optimal catalytic pyrolysis conditions for bio-oil production from brown salwood (Acacia mangium Willd) residues. Biomass and Bioenergy, v. 106, p. 127-136, 2017.

DIN EN ISO 17225-3. ENplus Handbook for the Quality Certification of Wood Briquettes. V. 2.0, March 2016.

DUARTE, R.F.; SAMPAIO, R.A.; BRANDÃO JR. D.S.; SILVA, H.P.; PARREIRAS, N.S.; NEVES, J.M.G. Initial growth of Acacia mangium grow cultivated in coconut fiber blanket with substratum of sewage sludge. Revista Árvore, v.35, n.1, p. 69-76, 2011.

INDÚSTRIA BRASILEIRA DE ÁRVORES. Relatório Ibá 2018. São Paulo. Disponível em: <http://iba.org/images/shared/Biblioteca/IBA_RelatorioAnual2018.pdf〉. Acesso em: 25 set. 2019.

LIU, Z.; FEI, B.; JIANG, Z.; CAI, Z.; LIU, X. Important properties of bamboo pellets to be used as commercial solid fuel in China. Wood Sci Technol, v. 48, p. 903-917, 2014.

LOPES, G.A., BRITO, J.O., MOURA, L.F. Uso energético de resíduos madeireiros na produção de cerâmicas no estado de São Paulo. Ciência Florestal, v. 26, p. 679-686, 2016.

MARQUEZ-MONTESINO F.; CORREA-MÉNDEZ F.; GLAUCO-SÁNCHEZ C.; ZANZI-VIGOUROUX, R.; RUTIAGA-QUIÑONES J.G.; AGUIAR-TRUJILLO L. Pyrolytic degradation studies of Acacia mangium wood. BioResources, v.10, n.1, p. 1825-1844, 2015.

MOYA, R. TENORIO, C. Fuelwood characteristics and its relation with extractives and chemical properties of ten fast-growth species in Costa Rica. Biomass and bioenergy, v. 56, p. 14-21, 2013.

POHLMANN J.G.; OSÓRIO E.; VILELA A.C.; DIEZ M.A.; BORREGO A.G. Integrating physicochemical information to follow the transformations of biomass upon torrefaction and low-temperature carbonization. Fuel, v. 131, p. 17-27, 2014.

REINA, L.; BOTTO, E.; MANTERO, C.; MOYNA, P.; MENÉNDEZ, P. Production of second generation ethanol using Eucalyptus dunnii bark residues and ionic liquid pretreatment. Biomass and Bioenergy, v. 93, p. 116 - 121, 2016.

ROSDIANA N.A.; DUMARÇAY S.; GERARDIN C.; CHAPUIS H.; SANTIAGO-MEDINA FJ, SARI RK, SYAFII W, GELHAYNE E, RAHARIVELOMANANA P, MOHAMMED R, GÉRARDIN P. Characterization of bark extractives of different industrial Indonesian wood species for potential valorization. Industrial crops and products, 108: 121-127, 2017.

FLORESTA, Curitiba, PR, v. 51, n. 1, p. 054-060, jan/mar 2021.

Souza, B. R. et.al.

ISSN eletrônico 1982-4688

DOI: $10.5380 /$ rf.v51 i1. 67299 
SETTE JUNIOR, C.R.; HANSTED, A. L. S.; NOVAES, E.; LIMA, P. A. F. E.; RODRIGUES, A. C.; SANTOS, D. R. S.; YAMAJI, F. M. Energy enhancement of the eucalyptus bark by briquette production. INDUSTRIAL CROPS AND PRODUCTS, v. 122, p. 209-213, 2018.

SETTE JUNIOR, C.R.; TOMAZELLO FILHO, M.; LOUSADA, J. L. P. C.; LOPES, D.; LACLAU, J. P. RELATIONSHIP BETWEEN CLIMATE VARIABLES, TRUNK GROWTH RATE AND WOOD DENSITY OF Eucalyptus grandis W. Mill ex Maiden TREES. Revista Árvore, v. 40, p. 337-346, 2016.

SILVA, C. L.; ROLDAO, B. C.; SANTOS, L. D. T.; HEIN, P. R. G. Lenho e Casca de Eucalyptus e Acacia em Plantios Monoespecíficos e Consorciados. Floresta e Ambiente, Seropédica, v. 25, n. 1, 2018.

VEGA, L. Y.; LOPEZ, L.; VALDÉS, C. F.; CHEJNE, F. Assessment of energy potential of wood industry wastes through thermochemical conversions. Waste Management, v. 87, p. 108-118, 2019.

ZHANG, G.J., SUN, Y.H., XU, Y. Review of briquette binders and briquetting mechanism, Renewable and Sustainable Energy Reviews, v. 82, p. 477-487, 2018.

ZHANG, L.; CHEN, J.; WANG, Y.; WU, D.; XU, M. Phenolic extracts from Acacia mangium bark and their antioxidant activities. Molecules, v 15, n. 5, p.3567-3577, 2010

FLORESTA, Curitiba, PR, v. 51, n. 1, p. 054-060, jan/mar 2021. 